Pietrzak M., Wilk J., Obszary metropolitalne Polski potudniowej a ruch migracyjny ludności, „Ekonomia i Prawo", Polszakiewicz B., Boehlke J. (red.), Tom XII, nr 3/2013, ss. 489-506. DOI: http://dx.doi.org/10.12775/EiP.2013.036

\author{
Michat Pietrzak*, Justyna Wilk**
}

\title{
OBSZARY METROPOLITALNE POLSKI POŁUDNIOWEJ A RUCH MIGRACYJNY LUDNOŚCI
}

\author{
STRESZCZENIE
}

W artykule zbadano relacje między obszarami metropolitalnymi Polski południowej a krajowym przepływem migracyjnym ludności w okresie 2008-2010. Regiony Polski południowej wykazują niskie natężenie przepływów wewnątrzregionalnych w porównaniu do pozostałych części kraju, ale intensywne ruchy międzyregionalne w obrębie analizowanego obszaru. Największe przepływy migracyjne dotyczą Wrocławia i Krakowa, zarówno w odniesieniu do regionów sąsiadujących, jak i dalszych, co potwierdza ich potencjał gospodarczy oraz metropolitalny charakter.

Słowa kluczowe: migracje wewnętrzne, obszary metropolitarne, taksonomiczny miernik rozwoju, migracje międzyregionalne

Klasyfikacja JEL: C00, J61, R11, R15

\section{METROPOLITAN AREAS OF SOUTHERN POLAND AND POPULATION MIGRATION MOVEMENT}

\author{
SUMMARY
}

The relations between metropolitan areas of southern Poland and domestic population migration flows in the period of 2008-2010 were discussed in this paper. Southern

* Michał Pietrzak, Uniwersytet Mikołaja Kopernika, Wydział Nauk Ekonomicznych i Zarządzania, Katedra Ekonometrii i Statystyki, tel.: +48 692800 52, e-mail: pietrzak@umk.pl (Autor wskazany do korespondencji).

** Justyna Wilk, Uniwersytet Ekonomiczny we Wrocławiu, Wydział Ekonomii, Zarządzania i Turystyki, Katedra Ekonometrii i Informatyki, tel.: +48 757-538-277, e-mail: justyna.wilk@ue.wroc.pl. 
Polish regions demonstrate low intensity of intraregional population movements while interregional flows are quite significant, within considering territory. The majority of migration flows occur in relation to the cities of Wrocław and Cracow, as regards neighbouring as well as remaining regions of Poland, due to their economic potential and metropolitan character.

Keywords: internal migration, metropolis, interregional migration

JEL Classification: C00, J61, R11, R15

\section{WSTĘP}

Procesy globalizacyjne oraz akcesja Polski w struktury Unii Europejskiej przyniosła dynamiczny wzrost i rozwój gospodarki krajowej. Taka sytuacja sprzyjała umacnianiu funkcji metropolitalnych największych ośrodków miejskich w kraju, a także konkurencyjności regionów, w których są one zlokalizowane.

W literaturze przedmiotu wskazywanych jest wiele definicji obszarów metropolitalnych, ich klasyfikacji oraz podejść i metod ich delimitacji ${ }^{1}$. Obszarem metropolitalnym określa się zazwyczaj taką strukturę osadniczą, w której występuje ośrodek centralny, stanowiący silnie zurbanizowany ośrodek miejski (ponad 500 tys. mieszkańców), wysoko rozwinięty pod względem gospodarczym.

Charakteryzuje się bogatym zapleczem gospodarczym (m.in. parki technologiczne, inkubatory przedsiębiorczości, centra transferu technologii), prężnie działającym rynkiem pracy i znacznym napływem kapitału zagranicznego. Pełni on również szereg innych funkcji, w tym administracyjnych, decyzyjnych, komunikacyjnych, turystycznych. Wykazuje dużą dostępność usług rynkowych i nierynkowych. Skupia instytucje naukowo-badawcze i edukacyjne, kultury, sportu, ochrony zdrowia itd. ${ }^{2}$ Obszar centralny nie pozostaje bez wpływu na regiony sąsiadujące, a także otoczenie dalsze. Oddziałuje na przepływy pro-

${ }^{1}$ Zob. np. Smętkowski M., Jałowiecki B., Gorzelak G., Obszary metropolitalne w Polsce: problemy rozwojowe i delimitacja, Raporty i analizy EUROREG 1, Warszawa 2009; Markowski T., Marszał T., Metropolie, obszary metropolitalne, metropolizacja. Problemy i pojęcia podstawowe, KPZK PAN, Warszawa 2006.

${ }^{2}$ Zob. np. Jałowiecki B., Globalny świat metropolii, Scholar, Warszawa; Batten D.F. (1995), Network cities: creative urban agglomerations for the 21st century, "Urban Studies" 2007, 32 (2), 313-328; Domański B., Metropolitan areas as "switching points" in the networks of relationships, W: T. Marszał, W. Zmitrowicz (red.), Metropolises and metropolitan areas - structure, functions and role 2007, PAN, Warszawa, 232-244. 
duktów i usług, kapitału, a także zasobów ludzkich, powodując wzmożony ruch migracyjny ludności ${ }^{3}$.

W Polsce ukształtowanym obszarem metropolitalnym jest miasto stołeczne Warszawa ${ }^{4}$, ale swoje funkcje wzmacniają również inne regiony kraju. Ich określenie wymaga jednak redefinicji obszaru metropolitalnego. Jednym z najważniejszych kryteriów, według których można zidentyfikować obszary metropolitalne w Polsce jest rozważenie przesłanek o charakterze ekonomicznym, a także zbadanie natężenia i kierunku przepływów migracyjnych ludności.

W Polsce występuje wyraźne zróżnicowanie terytorialne pod względem poziomu i tempa rozwoju regionalnego. Znaczne dysproporcje gospodarcze wykazują regiony zlokalizowane w południowej części kraju. $Z$ uwagi na położenie geograficzne, ukształtowanie terenu, koncentrację zasobów naturalnych poszczególne obszary spełniają różne funkcje, np. turystyczne, produkcyjne, zaplecza demograficznego itd. Znajdują się tam regiony o charakterze usługowym, przemysłowym i rolniczym.

Celem artykułu jest określenie potencjalnych obszarów metropolitalnych w Polsce południowej (województwa dolnośląskie, małopolskie, opolskie, podkarpackie, śląskie i świętokrzyskie) oraz rozważenie ich wpływu na zjawisko migracji krajowych w latach 2008-2010.

\section{OŚRODKI GOSPODARCZE POLSKI POŁUDNIOWEJ}

O poziomie rozwoju regionalnego, w tym ekonomicznym potencjale regionu stanowi profil gospodarczy, poziom produkcyjności, przedsiębiorczość, napływ kapitału zagranicznego, skłonność do przyciagania inwestycji, kondycja przedsiębiorstw i chłonność rynku pracy ${ }^{5}$. W ocenie sytuacji polskich podre-

3 Zob. np. White M.J., Lindstrom D.P., Internal migration, W: D.L. Poston, M. Micklin (red.), Handbook of population, Springer, Berlin-Heilderberg 2006, 311-345; Kupiszewski M., Rees P., Durham H., Internal migration and Urban Change in Poland, " European Journal of Population" 1998, Vol. 14, No. 3, 265-290.

${ }^{4}$ Zob. np. Korcelli-Olejniczak E., Berlin and Warsaw: in search of a new role in the European urban system, "Journal of Housing and the Built Environment" 2007, Vol. 22, No. 1, Globalization, Urban Systems, and Local Development, 51-68; Gawryszewski A., Korcelli P., Nowosielska E., Funkcje metropolitalne Warszawy, IGiPZ PAN, Warszawa1998.

${ }_{5}$ Zob. np. Strahl D. (red.), Metody oceny rozwoju regionalnego, Wyd. AE we Wrocławiu, Wrocław 2006; Dziemianowicz W., Łukomska J., Górska A., Pawluczuk M., Trendy rozwojowe regionów, GEOPROFIT, Warszawa 2009; Szewczuk A., Kogut-Jaworska M., Zioło M., Rozwwój lokalny i regionalny: teoria i praktyka, C.H. Beck, Warszawa 2011; Bal-Domańska B., Wilk J., Gospodarcze aspekty zrównoważonego rozwoju województw - wielowymiarowa analiza porównawcza, „Przegląd Statystyczny” 2011, nr 3-4, 300-322. 
gionów wytypowano zestaw cech diagnostycznych zawartych w tabeli 1. Analizę prowadzono na poziomie podregionów, spośród których sześć pokrywa się z granicami administracyjnymi największych w kraju miast na prawach powiatu. Wartości wskaźników pochodzą z 2008 r. W tym okresie Polska zaczęła odczuwać skutki światowego kryzysu finansowego i gospodarczego w postaci wyhamowania wzrostu gospodarczego.

Tabela 1. Zestaw cech opisujących potencjał gospodarczy podregionów

\begin{tabular}{|c|c|c|c|}
\hline NAzWA zMIENNEJ & CHARAKTER ZMIENNEJ & WARTOŚć WZORCA & $\begin{array}{c}\text { WARTOŚć ANTY- } \\
\text { WZORCA }\end{array}$ \\
\hline Wartość dodana brutto na 1 pracującego (zł) & Stymulanta & 136.953 & 48.712 \\
\hline $\begin{array}{c}\text { Osoby fizyczne prowadzące działalność gospodarczą } \\
\text { na 100 osób w wieku produkcyjnym }\end{array}$ & Stymulanta & 19 & 7 \\
\hline $\begin{array}{c}\text { Udział spółek handlowych z udziałem kapitału za- } \\
\text { granicznego na 100 podmiotów gospodarki narodo- } \\
\text { wej (sektor prywatny) (\%) }\end{array}$ & Stymulanta & 5,968 & 0,278 \\
\hline $\begin{array}{c}\text { Nakłady inwestycyjne w przedsiębiorstwach } \\
\text { per capita (zł) }\end{array}$ & Stymulanta & 12.024 & 1.053 \\
\hline $\begin{array}{c}\text { Udział pracujących w sektorze usług (rynkowych } \\
\text { i nierynkowych) w pracujących ogółem (\%) }\end{array}$ & Stymulanta & 83,3 & 27,0 \\
\hline Przeciętne miesięczne wynagrodzenie brutto (zł) & Stymulanta & $4.504,85$ & $2.401,06$ \\
\hline $\begin{array}{c}\text { Udział bezrobotnych zarejestrowanych w liczbie lud- } \\
\text { ności w wieku produkcyjnym (\%) }\end{array}$ & Destymulanta & 1,5 & 13,2 \\
\hline
\end{tabular}

Źródło: opracowanie własne na podstawie danych BDL GUS.

W analizie wykorzystano idę taksonomicznego miernika rozwoju (TMR), który pozwala ująć wszystkie wskaźniki jednocześnie i dokonać syntetycznej oceny sytuacji regionów ${ }^{6}$. Konstrukcja miernika obejmowała następujące kroki. W pierwszym kroku ustalono preferencje zmiennych. Większość zmiennych ma charakter stymulant, oprócz wskaźnika bezrobocia, który jest destymulantą. Następnie wyznaczono współrzędne obiektu-wzorca. Punkt odniesienia stanowił górny wzorzec rozwoju. Za najkorzystniejsze uznano wartości maksymalne dla stymulant i minimalne dla destymulant, osiągnięte w 2008 r. Następnie dokonano normalizacji wartości zmiennych za pomocą unitaryzacji zerowanej. Ujednolicono charakter zmiennych $\mathrm{w}$ drodze zamiany destymulanty na stymulantę przez odjęcie jej wartości od jedności.

Ustalono dystans każdego obiektu (podregionu) do obiektu-wzorca $\mathrm{z}$ wykorzystaniem odległości euklidesowej. Obliczono dla każdego podregionu

${ }^{6}$ Zob. np. Grabiński T., Wydymus S., Zeliaś A., Metody taksonomii numerycznej w modelowaniu zjawisk spoteczno-gospodarczych, PWN, Warszawa 1989; Młodak A., Analiza taksonomiczna w statystyce regionalnej, Difin, Warszawa 2006. 
wartość TMR z wykorzystaniem metody Hellwiga (1968). Przedział wartości miernika podzielono, $\mathrm{z}$ wykorzystaniem metody trzech średnich, na cztery klasy obrazujące relatywnie wysoki, umiarkowany, niski i bardzo niski poziom rozwoju gospodarczego.

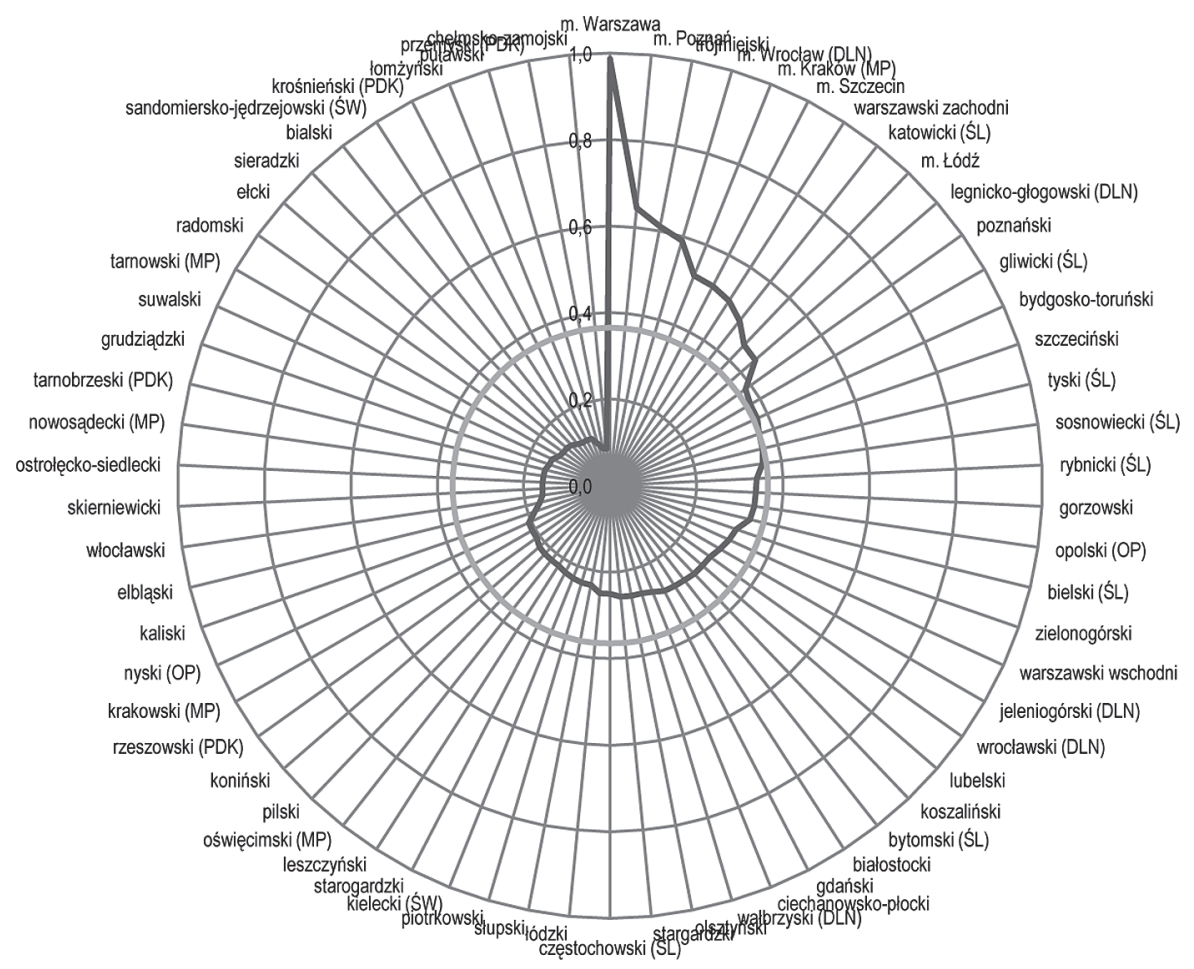

- podreaionv Polska

Rysunek 1. Rozrzut wartości miernika TMR dla 66 podregionów Polski w 2008 r.

Objaśnienia: DLN - dolnośląskie, MP - małopolskie, OP - opolskie, PDK - podkarpackie, ŚL - śląskie, ŚW - świętokrzyskie.

Źródło: opracowanie własne na podstawie danych GUS.

Wartość TMR bliską wzorcowej $(0,987)$ odnotowano w m. Warszawa, które stanowi obecnie najważniejszy obszar metropolitalny w Polsce (zob. rysunek 1.). Dzieli je znaczny dystans w stosunku do pozostałych regionów kraju. Wartość najniższą miernika $(0,086)$ uzyskał podregion chełmsko-zamojski województwa lubelskiego. 
Wśród podregionów Polski południowej występuje bardzo duże zróżnicowanie w zakresie rozwoju gospodarczego, szczególnie podregiony południowo -wschodnie wykazują znaczny dystans rozwojowy w stosunku do pozostałych obszarów. Do najsilniejszych ośrodków należą m. Wrocław (0,590), m. Kraków $(0,523)$, a także podregion katowicki $(0,484)$ i legnicko-głogowski $(0,444)$ (zob. rysunek 2.). Znajdują się one w pierwszej dziesiątce najlepiej rozwiniętych gospodarczo podregionów Polski.

\section{Poziom rozwoju gospodarczego}

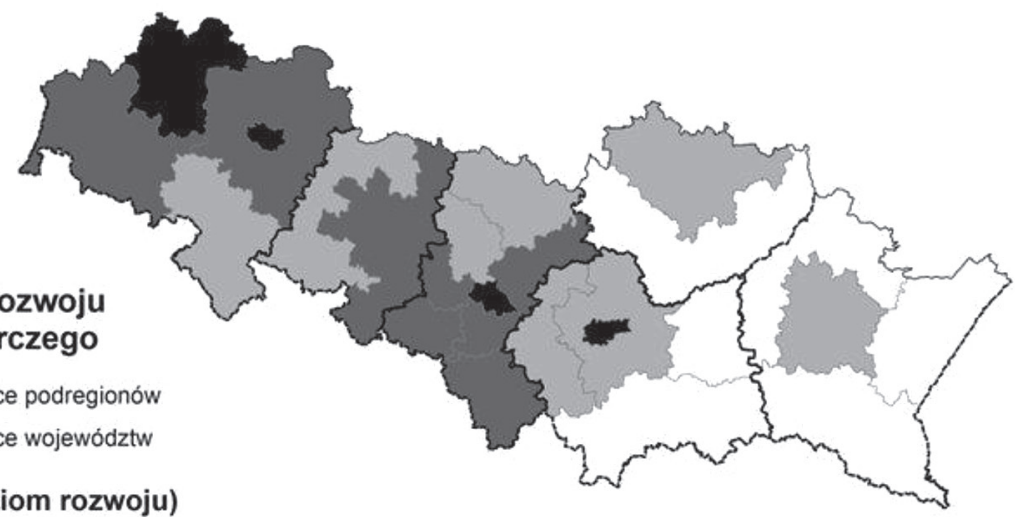

\section{klasa (poziom rozwoju)}

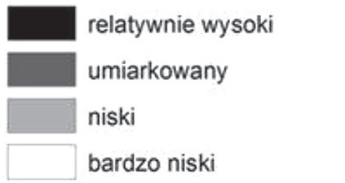
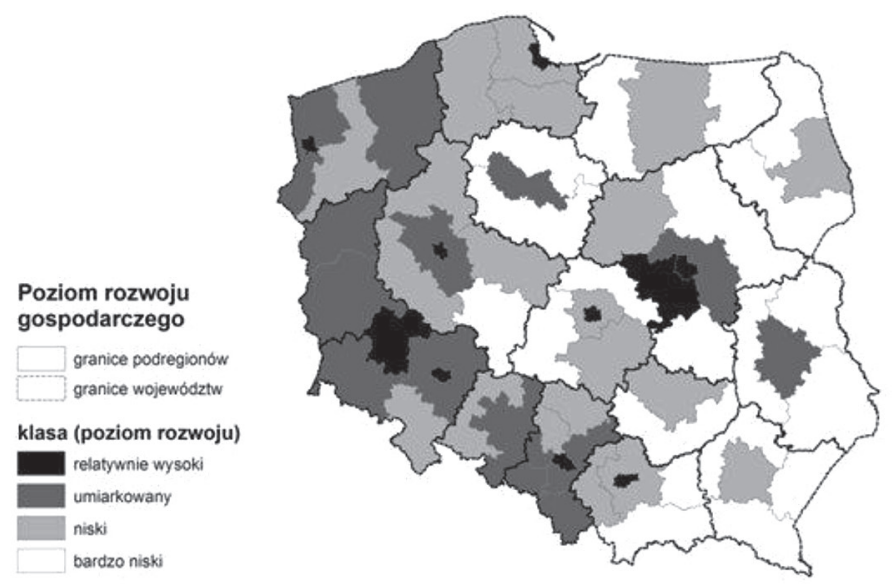

Rysunek 2. Sytuacja gospodarcza podregionów Polski południowej w 2008 r.

Źródło: opracowanie własne na podstawie danych BDL GUS. 


\section{SYTUACJA MIGRACYJNA POLSKI POŁUDNIOWEJ}

W okresie 2008-2010 w Polsce obserwuje się zmniejszenie natężenia krajowych ruchów migracyjnych i zawężenie grupy regionów docelowych ${ }^{7}$. W okresie wyhamowania gospodarczego wzrosła rola silnych ośrodków gospodarczych w kształtowaniu przepływów ludności. Województwami docelowymi w Polsce południowej stały się przede wszystkim małopolskie i dolnośląskie. Znaczny odpływ migracyjny nastąpił natomiast z województwa śląskiego, szczególnie w kierunku województwa mazowieckiego i małopolskiego.

Warto zauważyć, że województwa południowej Polski cechuje zróżnicowane natężenie wewnątrzregionalnych przepływów migracyjnych. Największą liczbę przemeldowań na pobyt stały, związanych ze zmianą granic administracyjnych gminy, odnotowano w województwie dolnośląskim, wysoka dotyczyła także śląskiego, opolskiego i podkarpackiego. Najsłabszą mobilność terytorialną wykazali mieszkańcy województwa świętokrzyskiego.

W badaniu przepływów migracyjnych zastosowano analizę wskaźnikową. W odniesieniu do podregionów skonstruowano wskaźnik przepływów wewnątrzregionalnych i wskaźnik napływu migracyjnego według kierunku. Wskaźniki wyznaczono jako zagregowane udziały przepływów migracyjnych dla okresu 2008-2010 w średniej liczbie ludności regionu docelowego (obecnego miejsca zameldowania). Wartości wskaźnika przepływów wewnątrzregionalnych podzielono na trzy, równe pod względem liczebności klasy (słabe, średnie i silne przepływy) ${ }^{8}$. Ilustrując wartości wskaźnika napływu migracyjnego według kierunku zobrazowano pięć grup przepływów ${ }^{9}$, tj. przepływy bardzo silne, silne i średnie (w tym średnie klasy I, II i III). Nie interpretowano przepływów słabych.

7 Zob. np. Wilk J., Pietrzak M., Matusik S., Sytuacja spoteczno-gospodarcza jako determinanta migracji wewnętrznych w Polsce, [w:] K. Jajuga, M. Walesiak (red.), „Taksonomia. Klasyfikacja i analiza danych - teoria i zastosowania” 2013, PN UE we Wrocławiu nr 20-21 (w druku).

${ }^{8}$ Klasy utworzone zostały na podstawie wartości wybranych centyli $\left(\min , \mathrm{C}_{33}\right),\left(\mathrm{C}_{34}, \mathrm{C}_{66}\right)$, $\left(\mathrm{C}_{67}, \mathrm{max}\right)$. Odnosząc się do wielkości przepływów, klasy nazwane zostały jako słabe, średnie i silne.

${ }^{9} \mathrm{~W}$ tym przypadku klasy nie zostały utworzone na podstawie wszystkich wartości wskaźnika przepływów migracyjnych, a jedynie dla jego największych wartości. Jest to podyktowane faktem istnienia 4290 wartości wskaźnika. Do wyznaczenia klas wykorzystano wartości centyli. Kolejno utworzono klasę „bardzo silne”, stanowiącą 2\% największych przepływów migracyjnych w kraju, której wartości należały do przedziału ( $\mathrm{C}_{98}$, max). Klasę „silne” dla przedziału $\left(\mathrm{C}_{96}, \mathrm{C}_{98}\right)$, klasę „średnie klasy I” dla $\left(\mathrm{C}_{94}, \mathrm{C}_{96}\right)$, klasę „średnie klasy II” dla $\left(\mathrm{C}_{92}, \mathrm{C}_{94}\right)$ oraz klasę „średnie klasy III” dla $\left(\mathrm{C}_{90}, \mathrm{C}_{92}\right)$. 
Dodatkowo wyznaczono wartości wskaźnika salda migracji, napływu oraz odpływu w odniesieniu do powiatów, na podstawie liczby osób zameldowanych i wymeldowanych - zagregowanej dla okresu 2008-2010 - w średniej liczbie ludności w tym okresie. Wartości wskaźnika podzielone zostały na pięć klas za pomocą metody podziału naturalnego. Odnosząc się do poziomów wskaźnika klasy nazwane zostały jako bardzo niski, niski, średni, wysoki i bardzo wysoki poziom salda migracji, przy czym dwie ostatnie dotyczyły dodatnich wartości współczynnika.
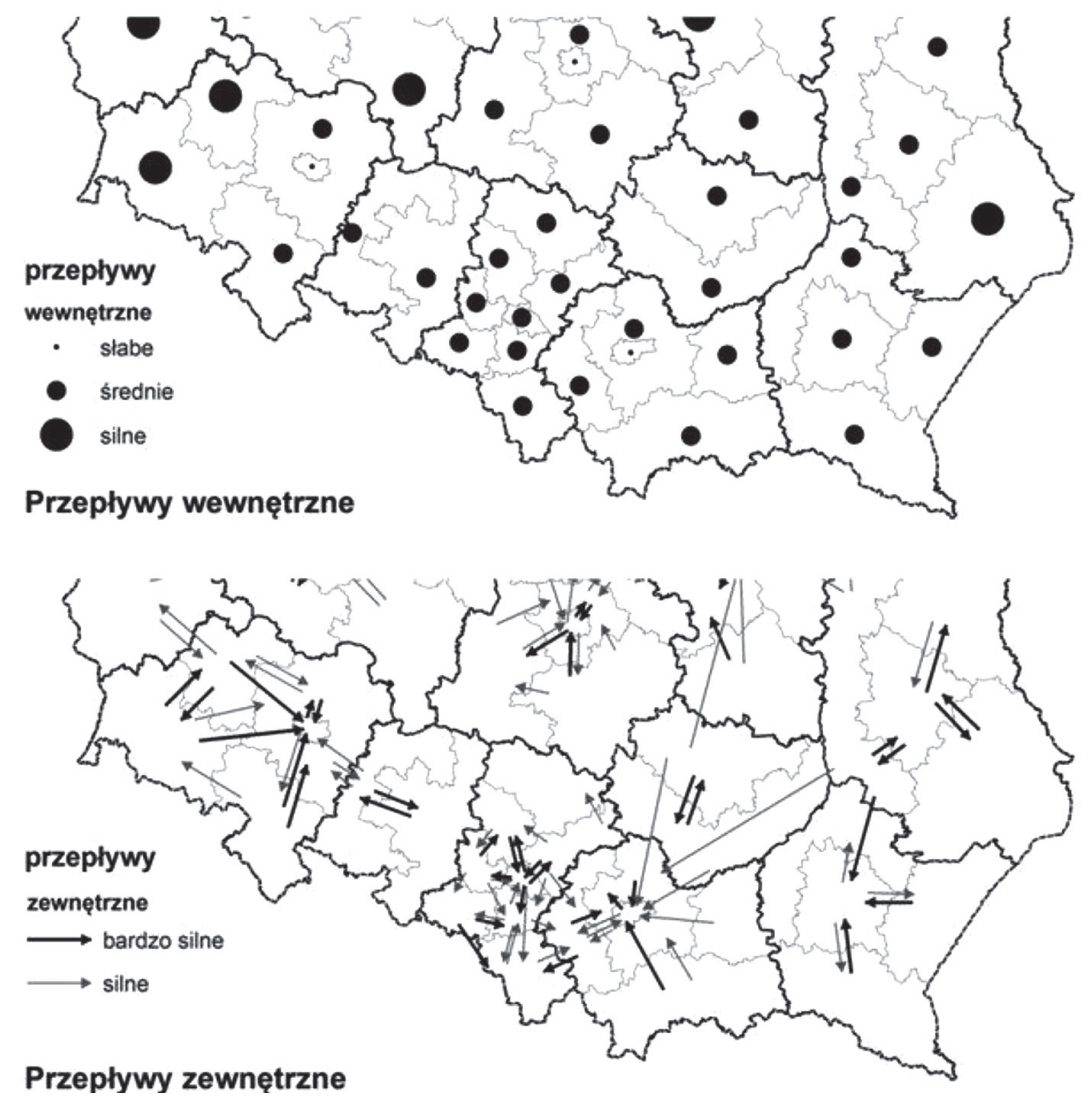

Rysunek 3. Natężenie przepływów migracyjnych wewnątrz podregionów Polski10 oraz silnych przepływów między podregionami

Źródło: opracowanie własne na podstawie danych BDL GUS.

${ }^{10}$ Zgodnie z metodologią GUS, przepływy ludności w obrębie miast na prawach powiatu nie są traktowane jako ruchy migracyjne, nie wiążą się z przekroczeniem granic administracyjnych gminy. $Z$ tego względu Wrocław i Kraków nie wykazują wewnątrzregionalnych przepływów migracyjnych. 
W południowej Polsce największe natężenie przepływów wewnątrzregionalnych występowało $\mathrm{w}$ przypadku podregionu legnicko-głogowskiego oraz jeleniogórskiego. $\mathrm{W}$ pozostałych podregionach występuje umiarkowane natężenie wewnątrzregionalnych ruchów migracyjnych (zob. rysunek 3.). Zaobserwować można natomiast znaczne ruchy ludności odbywające się między podregionami tego obszaru (zob. rysunek 3. i 4.). Warto zauważyć, że nie zachodzi istotny odpływ migracyjny w kierunku podregionów pozostałej części kraju.

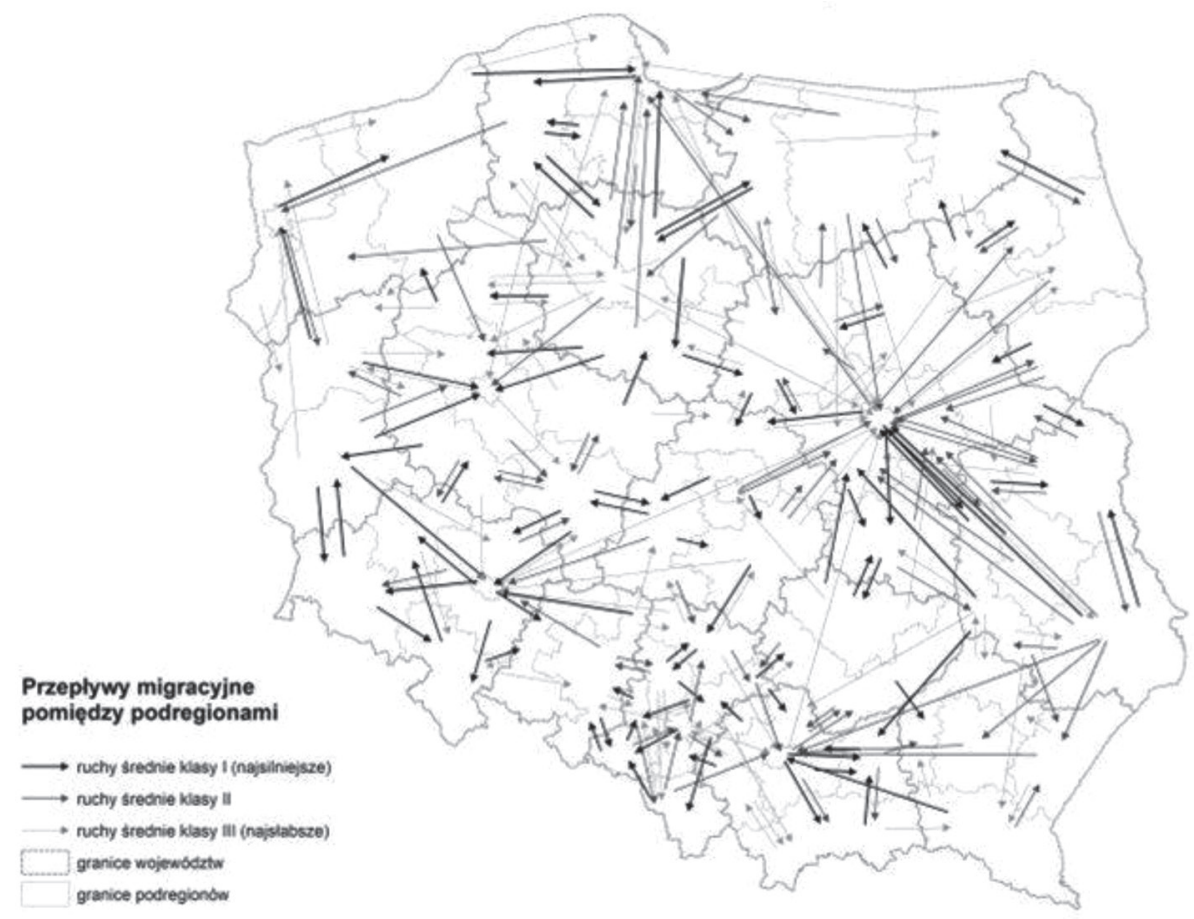

Rysunek 4. Kierunki i natężenie średnich przepływów migracyjnych między podregionami Źródło: opracowanie własne na podstawie danych BDL GUS.

\section{WPŁYW OBSZARÓW METROPOLITALNYCH POLSKI POŁUDNIOWEJ NA RUCH MIGRACYJNY}

Silne ruchy migracyjne w obszarze województwa dolnośląskiego można zaobserwować między podregionem legnicko-głogowskim i podregionami w bliskiej od niego odległości. Przepływy te w przeważającej mierze mają charakter dwukierunkowy. Choć podregion legnicko-głogowski stanowi waż- 
ny ośrodek gospodarczy w województwie i kraju (10. lokata w rankingu krajowym), nie zaobserwowano symptomów, które wskazywałyby na kształtowanie się obszaru metropolitarnego w jego obrębie. Zasięg przepływów migracyjnych jest niewielki i dotyczy głównie podregionów bezpośrednio sąsiadujących, szczególnie jeleniogórskiego.

Najważniejszym motorem rozwoju regionalnego województwa dolnośląskiego, a także istotnym ośrodkiem gospodarczym w skali całego kraju, jest m. Wrocław (4. lokata pod względem poziomu rozwoju gospodarczego w kraju). Stanowi on rozwijający się obszar metropolitarny, co przekłada się występowanie znaczących ruchów migracyjnych, spośród których większość stanowi napływ migracyjny.

Między Wrocławiem a pozostałymi podregionami zachodzą znaczne przepływy migracyjne ludności. Największe ruchy dotyczą podregionów bezpośrednio z nim sąsiadujących, zlokalizowanych na terenie województwa dolnośląskiego, tj. jeleniogórskiego, legnicko-głogowskiego, wałbrzyskiego i wrocławskiego. Większość tych przepływów ma charakter jednokierunkowy, w stronę Wrocławia.

Największa bilateralna wymiana zasobów ludzkich dotyczy w szczególności relacji Wrocław i okalającego go podregionu wrocławskiego. Bardziej szczegółowa analiza potwierdza występowanie zjawiska suburbanizacji, szczególnie w powiatach podregionu wrocławskiego bezpośrednio przylegających do Wrocławia, które wykazują wysokie dodatnie saldo migracji (zob. rysunek 5.).

Zasięg oddziaływania Wrocławia jest jednak znacznie szerszy (oddziałuje co najmniej na sąsiadów II-go rzędu); obejmuje także podregiony województw przylegających do dolnośląskiego, tj. lubuskiego, wielkopolskiego i opolskiego, a także dalszych zakątków kraju, w tym podregionu sieradzkiego i piotrkowskiego (woj. łódzkie), częstochowskiego (woj. śląskie), a także Warszawy (woj. mazowieckie).

W województwie opolskim istotne ruchy migracyjne dotyczą w szczególności dwustronnej wymiany między dwoma jego podregionami - nyskim i opolskim. Znaczące ruchy występują także w kierunku województw przylegających, tj. dolnośląskiego i śląskiego. Wymiana ma w znacznej mierze charakter dwukierunkowy, natomiast występuje również znaczny odpływ migracyjny z podregionu nyskiego do Wrocławia i napływ z podregionu katowickiego (woj. śląskie) do opolskiego.

Najwyższy wskaźnik zameldowań odnotowano w powiecie opolskim i m. Opolu, niemniej były to wartości mieszczące się dopiero w klasie $\mathrm{V}$ „wysokie wartości”. Niskie wartości wskaźnika występowały w powiatach brzeskim, namysłowskim i strzeleckim (klasa II „niskie wartości”). Wszystkie z powyższych powiatów przecina autostrada A4, co można interpretować jako zwiększone 


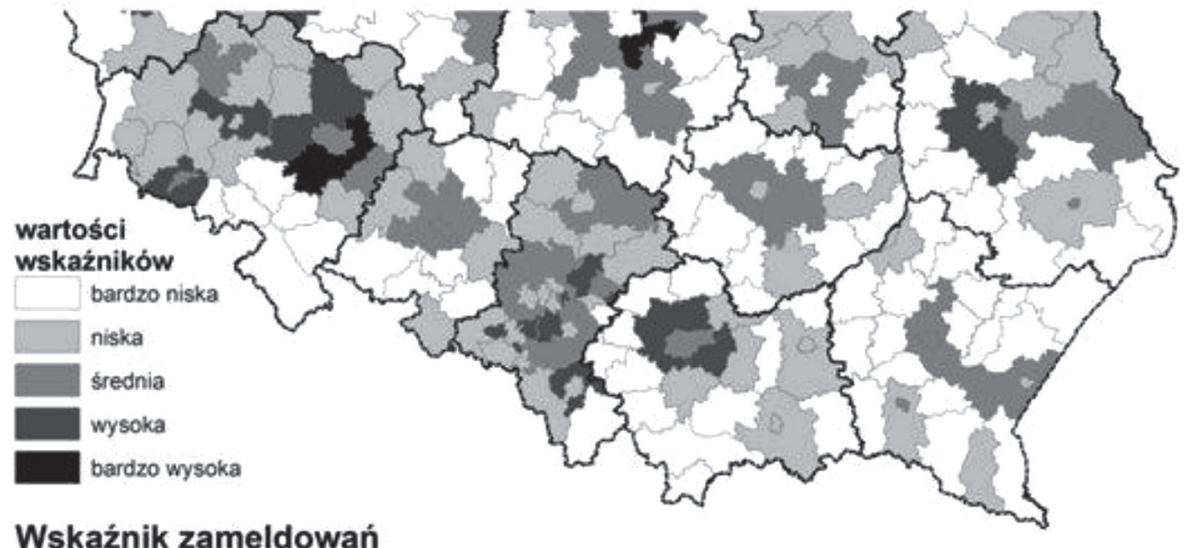

Wskaźnik zameldowań

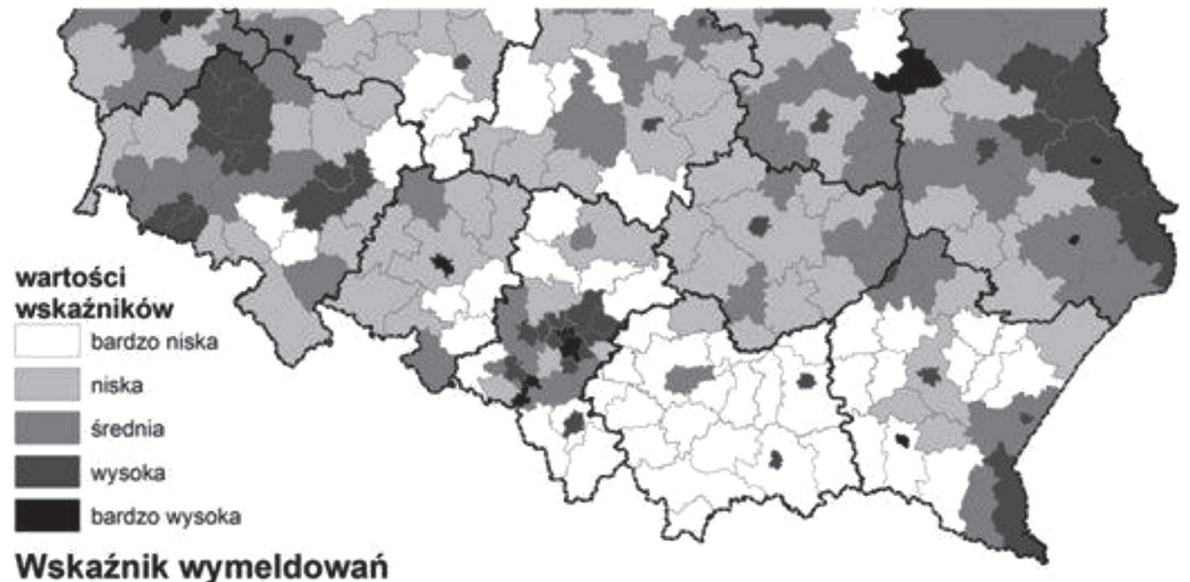

Wskaźnik wymeldowań

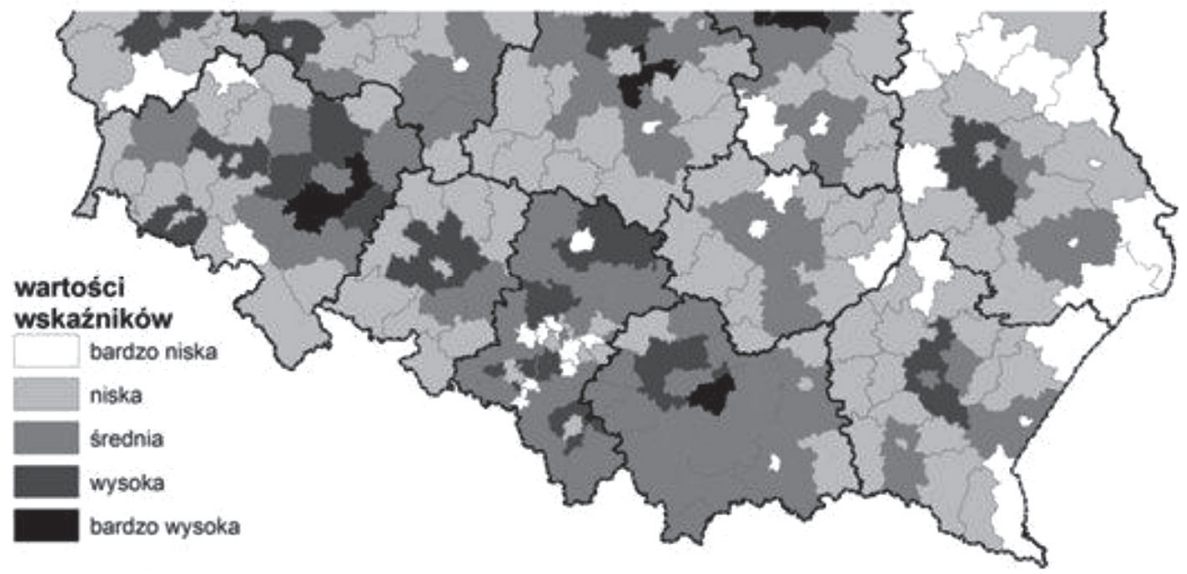

Rysunek 5. Wskaźnik napływu, odpływu oraz salda migracji dla powiatów Żródło: opracowanie własne na podstawie danych BDL GUS. 
zainteresowanie zamieszkaniem na terenach o ułatwionej akcesji do większych ośrodków miejskich (Wrocławia, Opola i miast Górnego Śląska). Niskie wartości wskaźnika w całym województwie świadczą o tym, że Opole czy Nysa, ze względu na bliskie sąsiedztwo bardziej rozwiniętych miast, nie pełnią funkcji metropolitalnych.

Najwyższy w województwie wskaźnik wymeldowań występuje w Opolu (klasa $V$ „bardzo wysokie wartości”), co jednak wynika ze wzmożonego ruchu w kierunku gmin ościennych i świadczy o postępującym zjawisku suburbanizacji. Wskaźniki mieszczące się w klasie IV „wysokie wartości” i klasie III „średnie wartości” występują w powiatach namysłowskim, głubczyckim, opolskim, kluczborskim, oleskim, brzeskim, nyskim oraz prudnickim. Wymeldowania z zachodniej części województwa odbywają się w kierunku Wrocławia i powiatu wrocławskiego. Saldo migracji jest dodatnie jedynie dla powiatów opolskiego oraz sąsiednich krapkowickiego i strzeleckiego. Wszystkie pozostałe powiaty stopniowo wyludniają się.

Podobna sytuacja, jak w przypadku opolskiego, dotyczy województwa świętokrzyskiego, w którym największe przepływy występują między jego dwoma podregionami, a także z podregionu kieleckiego w kierunku Warszawy i Krakowa. Średnie ruchy obserwowane są w odniesieniu do najbliższych podregionów województw sąsiadujących, głównie śląskiego, łódzkiego i mazowieckiego.

Najwyższy wskaźnik zameldowań (klasa III, „średnie wartości”) odnotowano w latach 2008-2010 w powiecie kieleckim. W Kielcach, powiatach buskim i opatowskim jego wartości należały do klasy II „niskie wartości”, a w pozostałych powiatach przyjęły wartości najniższe z klasy I „bardzo niskie wartości”. Można wnioskować, że Kielce jako jedyny większy ośrodek miejski w województwie posiada potencjał wielkomiejski. Można mówić o zachodzącym zjawisku suburbanizacji, czego potwierdzeniem jest najwyższa wartość wskaźnika wymeldowań (klasa IV „wysokie wartości”).

Nieco niższa wartość wskaźnika odpływu wystąpiła w powiatach opatowskim, sandomierskim, skarżyskim i pińczowskim (klasa III „średnie wartości”). W pozostałych powiatach wskaźnik przyjmował niskie wartości (klasa II „niskie wartości”). Wskaźnik w całym województwie nie przyjmuje wartości z klasy pierwszej „bardzo niska”, co stanowi o słabej jego pozycji.

Wskaźnik salda migracji jest nieujemny jedynie dla powiatu kieleckiego (klasa III „średnie wartości”), a najwięcej wymeldowań względem zameldowań wystąpiło dla Kielc, powiatów sandomierskiego i skarżyskiego (klasa I „bardzo niskie wartości”). Oznacza to, że Kielce jako jedyny większy ośrodek miejski w województwie nie pełni roli metropolitalnej. Mimo dodatniego salda dla regionów okalających, samo miasto wyludnia się. Podobnie jest w przypadku większości powiatów w województwie. 
Migracje wewnętrzne w województwie są przepływami najsilniejszymi na osi podregion kielecki i sandomiersko-jędrzejowski, symetrycznie w obu kierunkach. Należy zauważyć, że istnieją istotne przepływy migracyjne w kierunku Krakowa i Warszawy. W związku z tym trudno mówić o sile przyciągania i atrakcyjności gospodarczej województwa świętokrzyskiego. Jego struktura jest niewydolna, a Kielce nie są konkurencyjne względem nawet znacznie oddalonych ośrodków miejskich w kraju.

Znaczące ruchy migracyjne dokonują się również w obrębie województwa śląskiego i dotyczą w szczególności podregionów katowickiego, tyskiego i bielskiego. Między tymi podregionami a ich sąsiadami (w szczególności z najbliższego otoczenia) występuje dwustronna wymiana zasobów ludzkich. Wymiana między sąsiadami II-go rzędu zachodzi jedynie w odniesieniu do podregionu katowickiego, mającego silną pozycję gospodarczą w skali kraju (8. lokata), ale dotyczy relatywnie małych dystansów.

Dla województwa śląskiego najwyższe wartości wskaźnika zameldowań w latach 2008-2010 (klasa IV „wysokie wartości”) przyjął Chorzów oraz powiaty znajdujące się poza głównymi ośrodkami miejskimi: bielski, rybnicki, mikołowski i będziński. Wartości z klasy III „średnie wartości” przyjęły większe ośrodki miejskie jak Katowice, Mysłowice, Siemianowice Śląskie, Dąbrowa Górnicza, Żory i Piekary Śląskie, oraz powiaty gliwicki, tarnogórski, częstochowski, bieruńsko-lędziński i pszczyński. Niskie wartości współczynnika występowały w Rybniku, Jastrzębiu-Zdroju, Belsku Białej, Sosnowcu, Bytomiu, Zabrzu, Świętochłowicach, Gliwicach, Rudzie Śląskiej, Częstochowie, Tychach oraz powiatach cieszyńskim, kłobuckim, lublinieckim, myszkowskim, zawierciańskim, wodzisławskim i raciborskim (klasa II „niskie wartości”). Najniższy wskaźnik odnotowało Jaworzno i powiat żywiecki (klasa I „bardzo niskie wartości").

$Z$ uwagi na strukturę aglomeracyjną województwa, trudno na podstawie powyższej analizy stwierdzać jednoznacznie, wokół którego ośrodka zachodzą procesy suburbanizacyjne. Byłoby to możliwe podczas analizy województwa na poziomie gminnym. Jednak można zauważyć, że powiaty województwa przyjmują wysokie wartości współczynnika w odniesieniu do reszty kraju. Dodatkowo najczęściej jako docelowe wybierane są powiaty niebędące ośrodkami miejskimi, jednak leżące w ich bliskiej odległości.

Wartości wskaźnika wymeldowań grupują się bardzo wyraźnie w województwie śląskim. Największe w skali kraju wartości (klasa V „bardzo wysokie wartości”) odnotowano w Żorach i Jastrzębiu-Zdroju oraz Świętochłowicach, Chorzowie, Siemianowicach Śląskich i Katowicach. Wysokie wartości stanowią otoczenie wyżej wymienionej grupy powiatów, Rybnik oraz Tychy, Mysłowice, Sosnowiec, Dąbrowa Górnicza, Piekary Śląskie, Zabrze, Gliwice 
i powiat będziński, a także Bielsko-Biała. Średnie wartości wskaźnika przyjęły nieco bardziej oddalone powiaty, tj. rybnicki, pszczyński, gliwicki, bieruńsko-lędziński oraz Częstochowa (klasa III „średnie wartości wartości”). Niskie wartości wystąpiły w powiatach częstochowskim, tarnogórskim, mikołowskim, wodzisławskim i Jaworznie (klasa II „niskie wartości”). Analiza przepływów migracyjnych pozwala zauważyć prawidłowość $\mathrm{w}$ rozmieszczeniu wartości wskaźników, która świadczy o nasileniu zjawisk negatywnych, odpychających przepływy migracyjne od sześciu miast województwa (Żory, Jastrzębie-Zdrój, Świętochłowice, Chorzowie, Siemianowice Śląskie i Katowice).

Saldo migracji w województwie śląskim jest ujemne dla powiatu zawierciańskiego oraz wszystkich miast na prawach powiatu za wyjątkiem Chorzowa. Dla Gliwic, Żor, Jastrzębia-Zdroju, Tychów, Katowic, Sosnowca, Bytomia i Zabrza wartości współczynnika są najniższe w kraju (klasa I „bardzo niskie wartości”). Wskaźnik przyjął wysokie wartości w powiatach bielskim, rybnickim, mikołowskim, tarnobrzeskim i częstochowskim (klasa IV „wysokie wartości”).We wszystkich pozostałych powiatach wskaźnik jest dodatni (klasa III „średnie wartości”), co wskazuje wyraźnie tendencje do suburbanizacji. Jest ona tym łatwiejsza, że województwo śląskie jest regionem o największy skupisku autostrad.

Ruchy migracyjne w województwie rzadko wychodzą poza jego granice i na ogół są symetryczne. Są to jednak znaczne przepływy w skali kraju. Prawie wszystkie miasta wyludniają się, ale realizują przy tym bardzo dobrze swoją funkcję, przyciągając ludność na teren całego województwa. Aglomeracja Górnośląska jest regionem specyficznym, ale spełnia funkcje obszaru metropolitalnego.

Województwo małopolskie wyróżnia się pod względem znaczących przepływów w odniesieniu do dwóch podregionów, tj. oświęcimskiego oraz m. Krakowa. Podregion oświęcimski dokonuje wymiany zasobów głównie z podregionami sąsiadującymi, na krótkich dystansach, bądź Krakowem. Z kolei Kraków stanowi silny ośrodek gospodarczy, w skali kraju zajmuje piątą lokatę (po Wrocławiu). Jest głównym ośrodkiem napływu ludności zarówno z obszaru województwa małopolskiego, jak też dalszych podregionów. Przyciąga również przepływy migracyjne do podregionów sąsiadujących. Powiaty okalające Kraków reprezentują wysokie dodatnie salda migracji. Kraków pełni zatem rolę rozwijającego się obszaru metropolitalnego.

Najwyższy wskaźnik ${ }^{11}$ zameldowań odnotowano w powiatach krakowskim i wielickim (klasa IV „wysokie wartości”). Oba powiaty graniczą bezpośred-

\footnotetext{
11 wartości mieszczące się czwartym kwintylu czyli wyższe niż 60\% wyników i niższe niż 20\% najwyższych wyników.
} 
nio z Krakowem i stanowią całość jego najbliższego sąsiedztwa, co w wyniku suburbanizacji prowadzi do tendencji osiedlania się poza granicami największych miast, ale w odległości odpowiedniej do korzystania z usług wyższego szczebla. Dla miasta Krakowa wskaźnik znalazł się w (klasa III „średnie wartości”). Niskie wartości wskaźnika wystąpiły w powiatach proszowickim, bocheńskim i myślenickim (klasa II „niskie wartości”). Taki rozkład relatywnie wysokich wartości potwierdza metropolitalne znaczenie Krakowa. Niskie wartości wystąpiły także w miastach Tarnowie i Nowym Sączu oraz odpowiednio w powiatach tarnowskim i nowosądeckim (klasa II ,niskie wartości”). W pozostałych powiatach województwa wskaźnik zameldowań przyjmował bardzo niskie wartości (klasa I „bardzo niskie wartości”).

Wysokie wskaźniki wymeldowań dotyczą wyłącznie miast na prawach powiatu tj. Krakowa (klasa IV „wysokie wartości”) oraz Tarnowa i Nowego Sącza (klasa IV „wysokie wartości”). Wymeldowania dotyczące Krakowa mogą świadczyć o dynamice wewnętrznej większego miasta, natomiast wysokie wartości dla pozostałych miast na prawach powiatu należy już wiązać $\mathrm{z}$ niewydolnością struktury gospodarczej. W pozostałych powiatach, wskaźnik utrzymuje się na poziomie bardzo niskim (klasa I „bardzo niskie wartości”).

Najwyższe saldo migracji w województwie występuje w powiecie wielickim i mieści się w klasie $\mathrm{V}$ „bardzo wysokie wartości”. Wysokie, dodatnie wartości wskaźnika występują w powiecie krakowskim oraz powiatach proszowickim, bocheńskim, myślenickim, suskim i wadowicki (otoczenie Krakowa), co prowadzi do wniosku o jego znaczeniu metropolitalnym. Dodatnie wartości występują także w powiecie tatrzańskim, co z kolei można wiązać z walorami krajobrazowymi regionu oraz w otoczeniu Tarnowa i Nowego Sącza tj. w powiatach tarnowskim i nowosądeckim. W pozostałych powiatach wartości wskaźnika salda migracji są ujemne, a najniższy wskaźnik (klasa I „bardzo niskie wartości”) odnotowano w Nowym Sączu.

W latach 2008-2010 w województwie małopolskim dominowały migracje wewnętrzne na poziomie średnim, wśród których Kraków był zarówno celem jak i źródłem przemieszczeń. Silne przemieszczania w obu kierunkach występowały $\mathrm{z}$ województwem śląskim, natomiast w przypadku województwa świętokrzyskiego dominowały przepływy w kierunku Krakowa i powiatów ościennych. Na podstawie powyższych analiz można zarysować strukturę województwa małopolskiego z Krakowem o znaczeniu metropolitalnym wraz z jego szeroką strefą wpływów. Nowy Sącz i Tarnów traktować można jako miasta satelity, o słabnącej funkcji.

$\mathrm{Na}$ tle pozostałych województw Polski południowej relatywnie słabą mobilność terytorialną reprezentuje województwo podkarpackie, podobnie jak świętokrzyskie. Głównym obszarem uczestniczącym w ruchach migracyjnych 
jest podregion rzeszowski, a ruchy odbywają się na krótkich dystansach, w stosunku do podregionu krośnieńskiego i przemyskiego mają charakter bilateralny. Widać także duży napływ ludności z podregionu puławskiego województwa lubelskiego.

Najwyższy wskaźnik zameldowań odnotowano w Krośnie, Rzeszowie i powiecie rzeszowskim oraz w powiecie przemyskim (klasa III „średnie wartości”). W klasie II „niskie wartości” znalazły się Przemyśl, Tarnobrzeg i powiat tarnobrzeski, powiat Krośnieński oraz leski. W pozostałych powiatach wskaźnik należy do klasy I „bardzo niskie wartości” i przyjmuje najniższe wartości w kraju. Należy stwierdzić, że w całym województwie występują niskie wartości wskaźnika zameldowań na tle Polski. Zauważalne jest powiązanie wyższych wartości wskaźnika z występowaniem większych ośrodków miejskich, miast na prawach powiatu. Można w tym przypadku mówić o postępującej urbanizacji i suburbanizacji, jednak na poziomie bardzo niskim.

Najwyższe wartości wskaźnika wymeldowań odnotowano w Krośnie (klasa V „bardzo wysokie wartości”), a wysokie odpowiednio w Przemyślu, Tarnobrzegu, Rzeszowie (klasa IV „wysokie wartości”). W przypadku tych podregionów stanowi to przesłanki do wyciągnięcia wniosku o postępującej suburbanizacji. Do klasy III „średnie wartości” należały powiaty tarnobrzeski, stalowowolski, przemyski i leski, a niskie wartości wskaźnika z klasy II „niskie wartości” występują w powiatach niżańskim, rzeszowskim, strzyżowskim, brzozowskim i lubaczowskim. W pozostałej części województwa wskaźnik przyjmuje najniższe wartości w kraju, które należą do klasy I „bardzo niskie wartości”. Oznacza to, że województwie podkarpackim najbardziej wyludniają się miasta na prawach powiatu oraz powiaty ościenne, a także dwa powiaty graniczące z Ukrainą i Słowacją.

Analiza salda migracji wskazuje na bardzo słabą sytuację społeczno-gospodarczą województwa. Jedynym większym ośrodkiem miejskim o dodatnich wartościach wskaźnika salda migracji jest Rzeszów (klasa III „średnie wartości”), a także powiaty rzeszowski (klasa IV „wysokie wartości”), łańcucki oraz krośnieński (klasa III „średnie wartości”). Najniższe wartości wskaźnika odnotowano w Tarnobrzegu, Przemyślu, powiatach stalowowolskim, lubaczowskim i bieszczadzkim (klasa I „bardzo niskie wartości”). Spośród czterech miast na prawach powiatu tylko Rzeszów i Krosno są na tyle wydolne, żeby skupiać lub gromadzić wokół siebie napływ migracyjny.

Analiza ruchów migracyjnych w województwie podkarpackim w latach 2008-2010 niesie za sobą wnioski dotyczące jego słabej kondycji gospodarczej i niewydolności większości ośrodków miejskich. W najlepszej sytuacji w województwie jest Rzeszów wraz z powiatami ościennymi, w przypadku których można mówić o zjawiskach urbanizacji i suburbanizacji. 


\section{ZAKOŃCZENIE}

Podregiony Polski południowej cechują się słabymi wewnątrzregionalnymi przepływami migracyjnymi. Nie zachodzi również znaczący odpływ migracyjny w kierunku pozostałej części kraju. $Z$ tego względu Polskę południową można traktować jako samowystarczalną pod względem organizacyjnym strukturę terenów osadniczych.

Największe ruchy migracyjne, w których uczestniczą analizowane podregiony odbywają się w obrębie obszaru Polski południowej, głównie między podregionami sąsiadującymi i w przeważającej większości mają charakter bilateralny. Im dalej położony jest obszar docelowy tym mniejsze jest natężenie ruchów migracyjnych. Dla niewielu podregionów (m.in. kieleckiego, krakowskiego, Krakowa i Wrocławia) zaobserwowano znaczne przepływy na większych dystansach, w odniesieniu do sąsiada II lub wyższego rzędu, w tym Warszawy.

W obszarze Polski południowej wyodrębnić można trzy obszary wzmożonego przepływu (napływu i odpływu) ludności, tj. Wrocław, Kraków i Górnośląski Okręg Przemysłowy. Stanowią one najsilniejsze ośrodki gospodarcze zlokalizowane w tej części kraju, przy czym cele większości przemieszczeń stanowią Wrocław i Kraków. Choć pod względem ekonomicznym oba miasta oraz Górnośląski Okręg Przemysłowy dzieli znaczny dystans w stosunku do Warszawy, to wykazują one istotny potencjał rozwojowy. Można je określić mianem rozwijających się obszarów metropolitalnych.

\section{BIBLIOGRAFIA}

Bal-Domańska B., Wilk J., Gospodarcze aspekty zrównoważonego rozwoju województw - wielowymiarowa analiza porównawcza, „Przegląd Statystyczny” 2011, nr 3-4, 300-322.

Batten D.F., Network cities: creative urban agglomerations for the 21st century, „Urban Studies" 1995, 32 (2), 313-328, http://dx.doi.org/10.1080/00420989550013103.

Domański B., Metropolitan areas as "switching points" in the networks of relationships, [w:] T. Marszał, W. Zmitrowicz (red.), Metropolises and metropolitan areas - structure, functions and role 2007, PAN, Warszawa, 232-244.

Dziemianowicz W., Łukomska J., Górska A., Pawluczuk M., Trendy rozwwojowe regionóww, GEOPROFIT, Warszawa 2009.

Gawryszewski A., Korcelli P., Nowosielska E., Funkcje metropolitalne Warszawy, IGiPZ PAN, Warszawa 1998. 
Grabiński T., Wydymus S., Zeliaś A., Metody taksonomii numerycznej w modelowaniu zjawisk spoteczno-gospodarczych, PWN, Warszawa 1989.

Jałowiecki B. (2007), Globalny świat metropolii, Scholar, Warszawa.

Korcelli-Olejniczak E., Berlin and Warsaw: in search of a new role in the European urban system, "Journal of Housing and the Built Environment" 2007, Vol. 22, No. 1, Globalization, Urban Systems, and Local Development, 51-68, http:// dx.doi.org/10.1007/s10901-006-9066-1.

Kupiszewski M., Rees P., Durham H. (1998), Internal migration and Urban Change in Poland, „European Journal of Population” 1998, Vol. 14, No. 3, 265-290.

Markowski T., Marszał T., Metropolie, obszary metropolitalne, metropolizacja. Problemy i pojęcia podstawowe, KPZK PAN, Warszawa 2006.

Młodak A. (2006), Analiza taksonomiczna w statystyce regionalnej, Difin, Warszawa.

Smętkowski M., Jałowiecki B., Gorzelak G., Obszary metropolitalne w Polsce: problemy rozwojowe i delimitacja, „Raporty i analizy EUROREG 1”, Warszawa 2009.

Strahl D. (red.), Metody oceny rozwoju regionalnego, Wyd. AE we Wrocławiu, Wroclaw 2006.

Szewczuk A., Kogut-Jaworska M., Zioło M., Rozwój lokalny i regionalny: teoria i praktyka, C.H. Beck, Warszawa 2011.

White M.J., Lindstrom D.P., Internal migration, W: D.L. Poston, M. Micklin (red.), Handbook of population, Springer, Berlin-Heilderberg, 311-345, 2006, http:// dx.doi.org/10.1111/j.1747-7379.2010.00841.x.

Wilk J., Pietrzak M., Matusik S., Sytuacja spoteczno-gospodarcza jako determinanta migracji wewnętrznych w Polsce, W: K. Jajuga, M. Walesiak (red.), „Taksonomia. Klasyfikacja i analiza danych - teoria i zastosowania" 2013, PN UE we Wrocławiu $\mathrm{nr}$ 20-21 (w druku). 